\title{
Level of Farmers' Participation In The International Institute Of Tropical Agriculture (IITA) Improved Spear Grass (Imperata Cylindrica) Control Project In Benue State
}

\author{
A. E. Agwu ${ }^{1}$ and M.O. Agada ${ }^{2}$ \\ ${ }^{1}$ Department of Agricultural Extension \\ University of Nigeria, Nsukka, Enugu State \\ E-mail: agwuekwe@hotmail.com; Phone: +234-8034024251 \\ ${ }^{2}$ Institute of Food Security \\ Federal University of Agriculture \\ Makurdi, Benue State, Nigeria \\ E-mail: maryagada98@yahoo.com; Phone: +234-8034964155
}

\begin{abstract}
This study examined the participation of farmers in the International Institute of Tropical Agriculture (IITA) spear grass (Imperata cylindrica) control project, which used the participatory research and extension paradigm. A sample of 60 small-scale yam farmers from three districts of Tarka Local Government Area of Benue State who participated in the IITA spear grass control project were randomly selected and interviewed in this study. Descriptive statistics were employed in data analysis. The result of the study indicated that majority (80\%) of the participants sourced herbicides from open markets, 98.3\% perceived that the cost of herbicides was high, $75 \%$ could use herbicides, $73.3 \%$ were not visited by extension agents, $71.7 \%$ did not belong to any social organization, while all the participants had no access to credit. However, the farmers were satisfied with the operation of 6 out of 12 project activities. The study also revealed that involvement of participants in project activities was highest at the consultative level where key decisions were made by project officials and farmers only contributed their views. The study concluded that participation of farmers in IITA spear grass control project has not empowered them with the skills, knowledge and experiences to take greater responsibility of increasing yam production and productivity. The results call for strategies aimed at improving farmers' participation in similar projects to enable them attain a level where they can continuously co-create innovations in order to cope, compete and survive.
\end{abstract}

Key words: Participatory, Research, Extension, Spear grass, Technology. 


\section{INTRODUCTION}

Nigeria has a population of approximately 140 million inhabitants (National Population Commission, 2009). Income per capita was estimated at US $\$ 1,036$ in 2006, and as many as 54\% of Nigerians were estimated to be living in poverty in 2006 (Central Bank of Nigeria, 2007). About 71\% of Nigerian population including

Benue inhabitants lived on less than one dollar (\$1) a day from 1994-2004 (Hilhorst, van Liere., de Koning., Abeda, Jolayemi and Saror, 2004). Benue State is acclaimed as the Nigeria's food basket with over $70 \%$ of its population depending on agriculture as their main source of income (Hilhorst et al, 2004). Therefore, accelerating agricultural growth through promoting yield-enhancing technologies is a key means of eradicating poverty and increasing food security in rural areas.

However, the negative effect of weeds continues to undermine some efforts to ensure food security and combat poverty (Chikoye, Avav, Ellis-Jones, Kormawa, Udensi, Tarawali and Nielson, 2005). One of such chronic weeds that has been a menace to sustainable food production in the forest/savanna transition zone of Nigeria is Imperata cylindrinca (spear grass) (Avav and Okereke, 1999). It is a common weed of legumes, cereals, roots and tuber crops, and plantations (Chikoye, Manyong and Ekeleme, 2000). Yields of annual crops are severely reduced by competition from Imperata. In Benue State of Nigeria, which accounts for about 90 percent of the total national production of soybean (Glycine max (L) Merr.), spear grass was found to be responsible for grain yield losses of 29-53 percent (Avav, 2000).

Imperata cylindrica is a noxious weed affecting all crops grown in the lowland sub humid savannas of West Africa. The increasing spread threatens the sustainability of rural livelihoods and the natural resource base. The weed has been identified as the major natural problem affecting many communities in Benue, Kogi, Cross River States and other parts of Nigeria (Chikoye, Ellis-Jones, Alum, Tarawali and Avav, 2005).

Technologies developed to control Imperata cylindrica have been used successfully in large estates and commercial farms where there is an ample supply of labour, capital and herbicides. However, very few have been widely adopted by small-scale farmers (Terry, Adjers, Akobundu, Anoka, Drilling, Tjitrosemito and Utomo, 1997). Concerns about the impact of weeds, particularly Imperata and Striga on agricultural production and productivity and the low adoption rate of the existing Imperata management technologies by small-scale farmers in Nigeria, especially in the savanna zone, prompted the International Institute of Tropical Agriculture (IITA) Ibadan to request financial assistance from the Department for International Development (DFID) to implement a 3-year participatory project (2002-2004) on Imperata and Striga control in Nigeria (Chikoye et al, 2005). The objectives of the project were to: 
1. identify, evaluate, and develop methods for controlling Imperata cylindrica.

2. disseminate improved Imperata management options using Participatory Research and Extension Approach (PREA); and

3. increase the capability of $\mathrm{NGOs/CBOs/research} \mathrm{institutions/private} \mathrm{sector} \mathrm{to}$ facilitate uptake of improved weed management practices in small-scale, disadvantaged farming communities.

The project employed Participatory Research and Extension Approach (PREA) to encourage farmers test improved Imperata control technologies. Globally, agricultural development organizations are convinced that participatory research and extension approaches (PREA) are a better way to promote the wide spread adoption of improved technologies (Hagmann, Chuma, Murwa and Connolly, 1998), hence the use of this model in promoting the adoption of improved Imperata management technologies in selected communities in Benue State. The forgoing, however, raises some pertinent questions such as: what are the institutional characteristics of the participants of the project? What is the level of participation of beneficiaries in the project? And what is the level of satisfaction of beneficiaries with the project?

The general objective of this study was to assess the level of farmers' participation in the International Institute of Tropical Agriculture (IITA) improved Imperata control project in Benue State with a view to learning lessons that could serve as a guide for the design and implementation of similar projects. The specific objectives were to:

1. analyze the institutional characteristics of respondents;

2. ascertain participating farmers' level of participation in the PREA process; and

3. determine participating farmers' level of satisfaction with the project;

\section{Hypothesis}

Based on the above objectives, the following null hypothesis was tested.

1. There is no significant difference between participants in their level of satisfaction with the IITA spear grass control project.

\section{METHODOLOGY}

The study was conducted in Benue State, Nigeria. The State is located east of the Rivers Niger-Benue Confluence within the Middle Belt Region, which is the transition zone from the diverse Southern and Northern ecologies. The State lies between Longitude $6^{0} 35 \mathrm{E}$ and $10^{\circ} \mathrm{E}$ and Latitude $6^{\circ} 30 \mathrm{~N}$ and $8^{0} 10 \mathrm{~N}$ (Benue Agricultural and Rural Development Authority, 2005). The total land area is about 33.955 square kilometers (BNARDA, 2005). It is administratively divided into three agricultural zones namely; zones A, B and C comprising 23 Local Government Areas with an estimated population of 4.22 million (NPC, 2009). About $80 \%$ of the population is involved in subsistence farming, but of the 33,955 square kilometers 
of land in the state, only 23,000 square kilometers is available for arable and tree crop cultivation (BNARDA, 2005). Among the arable crops grown in the state are yam, cassava, sweet potatoes, cocoyam, groundnuts, soybeans, beniseed, rice, maize, millet, sorghum, bambaranuts, and pigeon pea while the tree crops include citrus, mango, cashew, plantain, banana, guava, and kolanut.

Multi-stage sampling procedure was used in the selection of respondents for the study. The first stage involved the purposive selection of the three project sites. The second stage involved the random selection of 20 project participants from each site. Thus, the total sample size of the study was 60 respondents.

A structured questionnaire containing relevant questions was employed for the study. The questionnaire was divided into three sections and each section contained relevant questions on the objectives. Section A sought information on the institutional characteristics of the respondents. Section B obtained information on the levels of participation of beneficiary farmers in the PREA process. Section $C$ sought information on farmers' satisfaction with the project.

Objective 1 was measured by asking the respondents questions on institutional characteristics. Objective 2 was measured using Biggs's (1989) four types of participation namely: contractual, consultative, collaborative and collegiate. Respondents were asked to score their participation in the PREA activities using a 4-point Likert-type scale ranging from contractual $=1$; consultative $=2$; collaborative $=3$; and collegiate $=4$. The respondent's mean score was computed for each operational activity under the IITA improved Imperata control project.

Objective 3, which elicited information on the satisfaction of participants, was measured on a 3-point Likert type scale ranging from very satisfied $=2$, satisfied $=$ 1 and not satisfied $=0$. These values were added to get a value of 3 which was divided by 3 to get a mean score of 1.0. The respondent mean was obtained on each of the items. Any variable with a mean score $\geq 1.0$ was regarded as satisfied; while any mean score less than 1.0 was regarded as not satisfied.

Objectives 1and 2 were analyzed using simple descriptive statistics such as frequency, percentages and mean. Objective 3 was analyzed by use of mean and chi-Square.

\section{RESULTS AND DISCUSSION}

\section{Sources of herbicides}

Majority $(80.0 \%)$ of the participants sourced herbicides through the open market (Table 1). However, 16.7\% participants got herbicides through extension organizations while $3.3 \%$ obtained farm inputs through input suppliers. This implies that majority of yam farmers got herbicides through the open markets. This general reliance on open markets for the purchase of herbicides could lead to high cost of production. Thus, there is need for extension organizations to effectively link farmers with input dealers who are distributors or directly to manufacturers. This finding also points to the need for input companies to establish sales outlets and/or agents close to the communities for easy access to these inputs. 


\section{Perceived cost of herbicides}

A greater proportion (98.3\%) of participants perceived that the cost of herbicides was high while $1.7 \%$ perceived that it was low (Table 1). With the high cost of herbicides, farmers are unlikely to be able to afford the product for use on a sustainable basis. According to Chikoye et al. (2005) the key to adoption of herbicide technology is the availability of herbicide supply to farmers on a sustainable basis and at subsidized rates.

\section{Ability to use herbicides}

Majority $(75.0 \%)$ of the participants could use herbicides on their farms while about $25 \%$ could not. This has implication for extension agencies in Benue State to strengthen the inherent capacities of yam farmers through workshops and in-farm training on the safe and effective use of herbicides.

\section{Frequency of extension agents' visit in the last twelve months}

A greater proportion (73.3\%) of participants had not had any contacts with the extension agents in the last twelve months (Table 1). However, $16.7 \%$ had between one and three contacts while $10.0 \%$ had between four and six visits by the extension agents. This implies that most farmers in the study area did not receive the necessary attention and support from the extension organizations/ agents. However, the report by the Agricultural Project Monitoring and Evaluation Unit (1997) indicated that the adoption of improved technologies was strongly and positively related to the frequency of visits by extension agents. Therefore, there is need for extension organizations/agents to improve the effectiveness of extension delivery among yam farmers through frequent visits to enhance their productivity.

\section{Membership of social organization}

A greater proportion (71.7\%) of participants did not belong to any social organization. In contrast, about $25.0 \%$ belonged to between one and two organizations while the remaining $3.3 \%$ were members of between three and four associations. This implies that most farmers were not members of any social organization. However, Unnayan (2010) noted that promotion of the farmers' organizations and reinforcing capacities of the producers will enhance access to improved services. This has implication for extension organizations to encourage farmers to form groups to enable them gain better access to resources, including herbicides for agricultural production and productivity.

\section{Access to credit}

All participants (100\%) had no access to credit facilities (Table 1). This implies that farmers would be unable to afford herbicides for weed control on their yam farms and so cannot exploit their full potentials for increased production of the commodity. 
TABLE 1: Percentage distribution of respondents by institutional characteristics $(n-60)$

\begin{tabular}{|c|c|c|c|c|}
\hline $\begin{array}{l}\text { Institutional } \\
\text { Characteristics }\end{array}$ & & Freq. & $\%$ & $\overline{\mathrm{X}}$ \\
\hline \multirow[t]{4}{*}{ Sources of herbicides } & Input dealers & 2 & 3.3 & \\
\hline & Open market & 48 & 80 & \\
\hline & $\begin{array}{l}\text { Extension } \\
\text { organization }\end{array}$ & 10 & 16.7 & \\
\hline & Total & 60 & 100 & \\
\hline \multirow{3}{*}{$\begin{array}{l}\text { Perceived cost of } \\
\text { herbicides }\end{array}$} & High & 59 & 98.3 & \\
\hline & Low & 1 & 1.7 & \\
\hline & Total & 60 & 100 & \\
\hline \multirow[t]{4}{*}{ Ability to use herbicides } & Yes & 45 & 75 & \\
\hline & No & 15 & 25 & \\
\hline & Total & 60 & 100 & \\
\hline & No visits & 44 & 73.3 & \\
\hline \multirow{3}{*}{$\begin{array}{l}\text { Frequency of extension } \\
\text { visit }\end{array}$} & $1-3$ & 10 & 16.7 & \\
\hline & $4-6$ & 6 & 10.0 & \\
\hline & Total & 60 & 100 & \\
\hline \multirow{4}{*}{$\begin{array}{l}\text { Membership of social } \\
\text { organization }\end{array}$} & None & 43 & 71.7 & \\
\hline & $1-2$ & 15 & 25 & \\
\hline & $3-4$ & 2 & 3.3 & \\
\hline & Total & 60 & 100 & \\
\hline \multirow[t]{3}{*}{ Access to credit facilities } & Yes & - & - & \\
\hline & No & 60 & 100 & \\
\hline & Total & 60 & 100 & \\
\hline
\end{tabular}




\section{Participation of farmers in IITA improved Imperata control project}

Entries in Table 2 show the varying degrees of involvement and control over decisions in the IITA improved Imperata control project. It reveals the extent to which local opinion and practice was given recognition in the project. The result indicates mean involvement of participants at contractual level in the following activities: planning for the next cropping season $(\bar{X}=0.10)$, project planning and design $(\bar{X}=0.30)$, managing "mother" trials $(\bar{X}=0.30)$, plan for training and capacity building of farmers $(\bar{X}=0.43)$ and managing of financial resources $(\bar{X}=$ 0.50 ). Similarly, consultative level of farmers' involvement were found in these activities: Joint analysis / priority setting of community weed problems $(\bar{X}=1.93)$, seeking solutions to identified problems $(\bar{X}=1.95)$, development of community action plans $(\overline{\mathrm{X}}=1.95)$, development of monitoring and evaluation indicators $(\overline{\mathrm{X}}=$ 1.92), contribution of labour and other services in "mother" trials $(\bar{X}=1.10)$, decision-making about experimental design and implementation ("daughter" trials) $(\bar{X}=1.97)$, and determination on the use of available resources $(\bar{X}=1.73)$. Furthermore, farmers were found to be collaborating in the following activities: managing of "daughter" trials $(\bar{X}=2.10)$, monitoring and evaluation of trials $(\bar{X}=$ $2.10)$, seasonal review of project process $(\bar{X}=2.10)$ and sharing of trial results $(\bar{X}$ $=2.03$ ). However, no farmer participated at the collegiate level.

The findings of this study show that participants were mostly involved at the consultative level where key decisions were made by the project officials, while farmers contributed their views. This implies that farmers' participation in the IITA spear grass control project has not empowered them in terms of their acquiring the skills, knowledge and experiences to take greater responsibility (Nelson and Wright, 1995; McCall, 1987; Mikkelsen, 1995). The non-attainment of participation at the collegiate level could be attributed to the project's short duration (2 years). Furthermore, this finding agrees with Bently (1994) who noted that while farmer participatory approaches can increase participation among farmers, it has not brought about impact and output; and may require more than short-term technology development (Humphries, Gonzalez, Jimemez and Sierra, 2000). 
TABLE 2: Mean score distribution of the perceived level of participation in improved Imperata control project activities by the participants $(\mathrm{n}-60)$

\begin{tabular}{|c|c|c|c|}
\hline Activities & $\begin{array}{c}\text { Level of } \\
\text { Participation }\end{array}$ & $\begin{array}{c}\text { Mean } \\
\text { score } \\
(\bar{X})\end{array}$ & $\begin{array}{l}\text { Std. } \\
\text { Dev. }\end{array}$ \\
\hline Project planning and design & Contractual & 0.30 & 0.64 \\
\hline $\begin{array}{l}\text { Joint analysis/priority setting of weed } \\
\text { problems }\end{array}$ & Consultative & 1.93 & 0.31 \\
\hline Seeking solutions to identified problems & Consultative & 1.95 & 0.30 \\
\hline Development of community action plans & Consultative & 1.95 & 0.30 \\
\hline Development of M\&E indicators & Consultative & 1.92 & 0.60 \\
\hline $\begin{array}{l}\text { Contribution of labour and services to } \\
\text { "mother" trials }\end{array}$ & Consultative & 1.10 & 0.77 \\
\hline Managing "mother" trials & Contractual & 0.30 & 0.72 \\
\hline $\begin{array}{l}\text { Decision-making about experimental } \\
\text { design and implication }\end{array}$ & Consultative & 1.97 & 1.43 \\
\hline $\begin{array}{l}\text { Plan for training and capacity building of } \\
\text { farmers. }\end{array}$ & Contractual & 0.43 & 0.90 \\
\hline $\begin{array}{l}\text { Determination on the use of available } \\
\text { resources. }\end{array}$ & Consultative & 1.73 & 1.45 \\
\hline $\begin{array}{l}\text { Operation and managing of "daughter" } \\
\text { trials. }\end{array}$ & Collaborative & 2.10 & 1.40 \\
\hline Monitoring and Evaluation of trials & Collaborative & 2.10 & 1.35 \\
\hline Management of financial resources & Contractual & 0.50 & 0.39 \\
\hline Sharing of trial results among farmers. & Collaborative & 2.10 & 1.34 \\
\hline Seasonal review of project process. & Collaborative & 2.03 & 1.36 \\
\hline Planning for the next cropping season. & Contractual & 0.10 & 0.54 \\
\hline
\end{tabular}

Note: Contractual $=<1.00 ;$ Consultative $=1.00-1.99 ;$ Collaborative $=2.00-2.99$;

Collegiate $=3.00-3.99$ 


\section{Satisfaction of participants with IITA improved Imperata control project}

Table 3 shows the result of the mean score distribution $(\bar{X})$ and the chi-square $\left(\chi^{2}\right)$ analysis of the relationship between the satisfaction variables of the participants. The data indicate that participants were satisfied with the operation of the following activities: situation analysis $(\bar{X}=1.43)$, respect for farmers' opinion $(\bar{X}=1.73)$, farmer selection $(\bar{X}=1.60)$, problem identification $(\bar{X}=1.40)$, and action planning $(\bar{X}=1.22)$ and benefits derived from the project $(\bar{X}=1.30)$. Conversely, the result shows that participants were unsatisfied with implementation of trials $(\bar{X}=0.82)$, monitoring and evaluation of project $(\bar{X}=0.80)$, sharing results amongst farmers $(\overline{\mathrm{X}}=0.97)$, farmer participation in project activities $(\overline{\mathrm{X}}=0.87)$, farmer control over project process $(\overline{\mathrm{X}}=0.37)$ and sustainability of the project after donor withdrawal ( $\overline{\mathrm{X}}=0.22$ ).

Furthermore, the analysis indicated that there were significant differences between the satisfaction variables among participants in the following areas: respect for farmers' opinion $\left(X^{2}=51.10\right)$, problem identification $\left(\left(X^{2}=30.10\right)\right.$, action planning $\left(X^{2}=55\right.$. 07), trial implementation $\left(X^{2}=12.10\right)$, monitoring and evaluation $\left(X^{2}=\right.$ $21.10)$, sharing of results $\left(X^{2}=10.90\right)$, benefits from project $\left(X^{2}=8.40\right)$, farmer control over project activities $\left(X^{2}=37.30\right)$ and sustainability of the project $\left(X^{2}=\right.$ 72.10). However, no significant differences were found among participants in situation analysis $\left(X^{2}=1.07\right)$, farmer selection $\left(X^{2}=1.67\right)$, and farmer participation in project activities $\left(X^{2}=4.30\right)$. This implies that there are significant differences between participants in their level of satisfaction with the IITA spear grass control project. 
TABLE 3: Test of hypothesis and mean score distribution on participants' perceived level of satisfaction with improved Imperata control project (n-60)

\begin{tabular}{lrrl}
\hline \multicolumn{1}{c}{ Variables } & $\begin{array}{c}\text { Mean score } \\
(\overline{\mathrm{X}})\end{array}$ & $\mathrm{X}^{2}$-cal & Asymp.Sig. \\
& 1.43 & 1.07 & 0.30 \\
\hline Situation analysis & 1.73 & 51.10 & $0.00^{*}$ \\
Respect for farmers' opinion & 1.60 & 1.67 & 0.20 \\
Selection of farmers & 1.40 & 30.10 & $0.00^{*}$ \\
Identification of problems & 1.22 & 55.07 & $0.00^{*}$ \\
Action planning & 0.82 & 12.10 & $0.00^{*}$ \\
Implementation on trials & 0.80 & 21.10 & $0.00^{*}$ \\
Monitoring and evaluation of project & 0.97 & 10.90 & $0.00^{*}$ \\
Sharing of results & 1.30 & 8.40 & $0.02^{*}$ \\
Benefits derived from the project & 0.87 & 4.30 & 0.12 \\
Farmer participation in project activities. & 0.37 & 37.30 & $0.00^{*}$ \\
Farmer control over project process. & 0.22 & 72.10 & $0.00^{*}$ \\
Sustainability of the project after donor & & & \\
withdrawal & & & \\
\hline
\end{tabular}

Note: Satisfied $=\geq 1 ;$ Not Satisfied $<1 ;{ }^{*}=p<0.05$

\section{CONCLUSION AND RECOMMENDATIONS}

The results of the study indicated that majority $(80 \%)$ of the participants sourced herbicides from open markets, $98.3 \%$ perceived that the cost of herbicides was high, $73.3 \%$ were not visited by extension agents, and none of the participants had access to institutional credit facilities. However, the farmers were satisfied with the operation of 6 out of 12 project activities.

The study further revealed that participants were mostly involved at the consultative level where key decisions were made by project officials and farmers only contributed their views. The study concluded that participation of farmers in IITA spear grass control project has not empowered them with the skills, knowledge and experiences to take greater responsibility of increasing yam production and productivity.

Based on the above conclusion, the following recommendations are made: 
1. The key to adoption of herbicide technology is by improving the availability of herbicide supply to farmers on a sustainable and subsidized basis. In addition, extension agents could organize small-scale yam farmers into groups and encourage them to pull their resources together for purchase of herbicides and other farm inputs. Extension agents could also train farmers on the effective use of chemicals on a continuous basis.

2. Project implementers should involve farmers from the onset of a participatory project and through the project life in order to enhance satisfaction and ownership.

3. To attain participation at the collegiate level for increased productivity and food security, donor agencies could consider supporting a long term technology development.

\section{REFERENCES}

Agricultural Projects Monitoring and Evaluation Unit (1997). Evaluation of the Effectiveness of Training and Visit Extension System in Nigeria: A research report. National Agricultural Extension and Liaison Services (NAERLS), Ahmadu Bello University, Zaria, pp 89-122.

Avav, T. and O.U. Okereke (1999). Pre-tillage control of speargrass (Imperata Cylindrica) with glyphosate for soybean (Glycine max) production. Indian Journal of Agricultural Sciences. 67 (8): 295-297.

Avav, T. (2000). Control of speargrass (Imperata Cylindrica (L) Rauschel) with glyphosphate and flauzifop-butyl for soybean (Glycine max (L) Merr) production in savanna Zone of Nigeria. Journal of Science of Food and Agriculture. 80: 193-196.

Benue Agricultural and Rural Development Authority (BNARDA) (2005). Implementation

Completion report on National Special Programme for Food Security (NSPFS), Benue State, Nigeria, pp1-23.

Bentley, J. (1994). Facts, Fantasies and Failures of Farmer Participatory Research. Agriculture and Human Values Vol. 11, No. 243, pp 140-150.

Biggs, S. (1989). Resource-poor farmer participation in research: a synthesis of experiences from nine National Agricultural Research Systems; OFCOR Project Study No. 3, pp. 3-37, ISNAR.

Central Bank of Nigeria (CBN) (2007). Central Bank of Nigeria Annual Report for the Year ended December, 2006.

Chikoye, D., V.M. Manyong and F. Ekeleme (2000). Characteristics of Spear grass (Imperata Cylindrica) dominated fields in West Africa: crops, soil properties, farmer perceptions, and management strategies. Crop Protection 21: 145-667. 
Chikoye, D., T. Avav, J. Ellis-Jones, P.M. Kormawa, U.E. Udensi, G. Tarawali, O.K. Nielson (2005). Promoting the use of integrated spear grass (Imperata Cylindrica (L.) Raeuchel) management practices in soybean, cassava, and yam in Nigeria. In: Chikoye, D., J. Ellis-Jones, A.F. Alum, G. Tarawali, and T. Avav (eds). Proceedings of the second Imperata Management Stakeholders' Conference, Makurdi, Nigeria. IITA Ibadan, Nigeria. pp 35-48.

Chikoye, D., J. Ellis-Jones, A.F. Alum, G. Tarawali, and T. Avav (2005). Reducing poverty through improved Imperata control. Proceedings of the second Imperata management stakeholders' conference, held in Makurdi, Benue State, Nigeria. IITA, Ibadan, Nigeria. 119pp.

Ellis-Jones, J., J. Power. D.Chikoye, O.K. Nielsen, P.M. Kormawa, S. Ibadan, G. Tarawali, U. Udensi and T. Avav (2003). Scaling-Up the use of improved Imperata management practices in sub-humid savanna of Nigeria. In the 2003 Brighton Crop Protection Conference. Weeds Proceedings'. International Conference, 17-20 November 2003, Brighton, Farnham, Survey: British Crop Protection Council. Pp 1011-1016.

Hagmann, E. Chuma, K. Murwa and M. Connolly (1998). Learning together through participatory extension: a guide to an approach developed in Zimbabwe, AGRITEX, Harare, Zimbabwe.

Hillhorst, T., M. van Liere., K. de Koning., F. Abeda., T. Jolayemi and S. Saror (2004). Impact of AIDS on rural livelihood in Benue State, Nigeria: Implications for policymakers. KIT/BNARDA, pp13-14.

Humphries, S., J., Gonzalez, J. Jimemez and F. Sierra (2000). Searching for Sustainable Land Use Practice in Hondras: Lessons from a programme of participatory research with hillside farmers. Overseas Development Institute. Agricultural Research and Extension Network Paper No. 104

McCall, M.K. (1987). Indigenous knowledge system as the basis for participation: East African potentials, Working Paper 36, Enschede; Technology and Development Group, University of Twente.

Mikkelsen, B. (1995). Methods for development work and research. A Guide to practitioners. Sage Publications, p 63.

National Population Commission (2009). 2006 Population and Housing Census of the Federal Republic of Nigeria. National and State Population and Housing Tables. Priority Tables, vol.1, pp 5-8.

Nelson, N. and S. Wright (1995). Power and participatory development. In: I. Guijt and M.K. Shah (eds.). Walking up to power, conflict and process. The myth of community: gender issues in participatory development. Intermediate technology Ltd, London, pp 1-19.

Unnayan, O. (2010). Agrarian Transition and Livelihoods of the Rural Poor: Agricultural Extension Services. The Innovator, Bangladesh. www.unnayan.org 
Terry, P.J., G. Adjers, I.O. Akobundu, A.U. Anoka, M.E. Drilling, S. Tjitrosemito, and M, Utomo (1997). Herbicides and Mechanical control of Imperata Cylindrica as a first step in grassland rehabilitation. Agro forestry Systems 36, pp 151-179. 